\title{
Lugemisoskuse ja -motivatsiooni seosed õpetajate kasvatusstiilidega esimeses klassis
}

\author{
Piret Soodla ${ }^{\mathrm{a}}$, Eve Kikas ${ }^{\mathrm{a}}$ \\ a Tallinna Ülikooli psühholoogia instituut
}

\begin{abstract}
Annotatsioon
Töö eesmärk oli analüüsida, kas ja kuidas erinevad esimese klassi laste lugemisoskus ja motivatsioon lapsekeskse, õpetajakeskse ja laps-domineeriva kasvatusstiiliga õpetajate klassides.

Uuringus osalesid 440 õpilast ja nende õpetajad $(N=21)$. Esimese klassi alguses ja lõpus hinnati laste lugemistehnilisi oskusi ning motivatsiooni (huvi ja tajutud võimekust), klassi lõpus ka loetu mõistmist. Igas klassis vaadeldi kolme õppetundi, klassitegevused kodeeriti vaatlusmõõdiku ECCOM abil (Stipek \& Byler, 2005). Vaatlustulemuste alusel jaotati õpetajad lapsekeskse $(n=8)$, õpetajakeskse $(n=7)$ ja laps-domineeriva $(n=6)$ kasvatusstiiliga õpetajateks.

Õpetajate lapsekeskne kasvatusstiil seostus positiivselt ning õpetajakeskne ja laps-domineeriv stiil negatiivselt laste lugemisoskuse ja -huviga. Uurimuse tulemused täiendavad varasemaid teadmisi õpetaja tegevuste ja laste oskuste ja motivatsiooni seostest ning neil on praktiline väärtus õpetajakoolituses.
\end{abstract}

Võtmesõnad: kasvatustegevused, kasvatusstiilid, lugemine, motivatsioon, huvi, tajutud võimekus

\section{Sissejuhatus}

Lugemaõppimine on üks olulisemaid eesmärke esimestel kooliaastatel. On teada, et loetust arusaamine eeldab mitmesuguseid kognitiivseid ja keelelisi oskusi (vt Cain, 2009; Oakhill \& Cain, 2007) ning motivatsioonitegureid (nt Aunola, Nurmi, Niemi, Lerkkanen, \& Rasku-Puttonen, 2002; Guthrie, Wigfield, \& Von Secker 2000; Wigfield \& Guthrie, 1997; Wilson \& Trainin, 2007). Viimasel aastakümnel on lugemisuuringutes suurt tähelepanu pööratud ka õpetaja tunnitegevustele, millel on samuti tugev mõju laste arengule (nt Connor et al., 2009a, 2009b; Lerkkanen et al.,

1 Psühholoogia instituut, Tallinna Ülikool, Narva mnt 29, 10120 Tallinn; piret.soodla@tlu.ee 
2012b; Wigfield, Guthrie, Tonks, \& Perencevich, 2004). Vaatlusmeetoditel põhinevaid pikiuuringuid on tehtud siiski vähe.

Eesti haridusvaldkonnas on suhteliselt palju arutletud selle üle, mida peaksid lapsed koolis oppima ning mis teadmised ja oskused omandama. Vähem on räägitud sellest, kuidas mõjutavad õppimist õpetaja tegevused tunnis. Et toetada laste oskuste arengut ja õpimotivatsiooni, on oluline teada, kuidas need seostuvad õpetajate tegevustega. Siinse töö eesmärk oli analüüsida, kas ja kuidas erinevad esimese klassi laste lugemisoskus ja motivatsioon lapsekeskse, õpetajakeskse ja laps-domineeriva kasvatusstiiliga õpetajate klassides.

\section{Lugemisoskuse ja -motivatsiooni seosed}

Lugemisoskus koosneb kahest kesksest komponendist: tehnilisest lugemisoskusest ja keelelisest mõistmisest (Hoover \& Gough, 1990). Lugemistehniliste oskuste all mõeldakse inimese suutlikkust üksiksõnu, lauseid või seotud teksti ilma vigadeta ja sujuvalt lugeda. Lugemistehniliste oskuste aluseks on seejuures sõnalugemisoskus, st sõnade kokkulugemise (dekodeerimise) ja äratundmise õigsus ja kiirus. Keelelise mõistmise all peetakse silmas verbaalsest infost arusaamist sõna-, lause- ja tekstitasandil. Nii lugemistehnilised kui ka keelelised oskused on lugemisel vajalikud ja puudujäägid neis põhjustavad raskusi loetu mõistmisel (Hoover \& Gough, 1990). Ladus lugemine toetab loetust arusaamist: kui lugemine on kiire ja veatu, jääb lugejal rohkem ressursse tähenduse konstrueerimiseks (Perfetti, 1994). Algajatel lugejatel on seos lugemistehniliste oskuste ja loetu mõistmise vahel tugev, kuid oskuste arenedes see nõrgeneb ning loetu mõistmise seisukohast muutuvad üha olulisemaks keelelised oskused, nt sõnavara tundmine ning järeldamis- ja seostamisoskus (vt Cain, 2009; Oakhill \& Cain, 2007).

Teksti lugemise käigus tuleb lugejal dekodeerida ja ära tunda sõnad, mõista sõnade tähendusi ja seostada need lausetes ning siduda lausete tähendused, et tekiks kujutlus tekstis kirjeldatust. Et teksti täielikult mõista, tuleb selles otseselt sisalduv teave seostada olemasolevate taustteadmistega ning teha teksti alusel üldistusi ja järeldusi. Selle protsessi tulemusena konstrueerib lugeja situatsioonimudeli ehk tervikliku ja seostatud kujutluse tekstis kirjeldatust (Kintsch, 1998, 2013). Situatsioonimudeli loomine ei õnnestu lugejal aga sugugi alati: see sõltub lugemistehnilistest oskustest, teksti mõistmise kognitiivsetest ja keelelistest osaoskustest ning lugeja taustteadmistest (Kintsch, 1998). Lastel, kellel need teadmised ja oskused on alles arenemisjärgus, tekib seetõttu loetu mõistmisel küllalt sageli probleeme. 
Teksti mõistmine eeldab peale lugemisoskuse ja teadmiste ka pingutamist ja püsivust, mistõttu avaldab õpilase motivatsioon õppimisele ja õpitulemustele suurt mõju. On mitmeid motivatsiooniteooriaid, kus käsitletakse mõneti erinevaid konstrukte. Siinses uurimuses toetusime ootusteväärtuste teooriale (expectancy-value theory, vt Eccles \& Wigfield, 2002; Wigfield \& Eccles, 2000), mis seletab õppimisel tehtavaid valikuid, pingutamist, püsivust ning õpisooritusi tajutud võimekuse (st toimetulekuga seotud ootuste) ja ülesande väärtustamise määraga ning mida interpreteerime lugemise kontekstis.

Tajutud võimekuse all mõeldakse õpilase usku suutlikkusse õppida või tegutseda soovitud tasemel (Bandura, 1986). Kooliteed alustavatel lastel on tajutud võimekus enamasti suur kõigis õppeainetes, kuid üldiselt see väheneb algklasside jooksul (Eccles, Wigfield, Harold, \& Blumenfeld, 1993) ning seostub üha enam lapse tegeliku oskuste tasemega (Stipek \& MacIver, 1989). Muutused tajutud võimekuses saavad alguse juba esimesel kooliaastal: esimese klassi talveks on laste hinnangud oma oskustele eri valdkondades juba mõnevõrra erinevad ning seotud ka vastavate oskuste tasemega (Eccles et al., 1993; Wilson \& Trainin, 2007). Peale isiklike kogemuste, mis saadakse tegelike õpitulemuste alusel, mõjutab tajutud võimekust lapse sotsiaalne keskkond, eeskätt õpetaja tagasiside ja julgustamine õppimisel ning eakaaslastega võrdlusest saadud info (Schunk, 1999; Zimmerman, 2000).

Ülesande väärtuse all peetakse silmas ülesande tähtsust, huvitavust ja kasulikkust lapse jaoks (Wigfield \& Eccles, 2000), millest meie pöörame tähelepanu huvile kui algklassides olulisele näitajale. Ülesande huvitavus seostub sisemise motivatsiooniga (Ryan \& Deci, 2000), mis tähendab, et ülesannet sooritatakse naudinguga ning ka pingutatakse rohkem.

Tajutud võimekusel ja lugemishuvil on positiivne mõju laste lugemisoskuse arengule. Õpilased, kes tajuvad end heade lugejatena ja kellele meeldib lugeda, on lugemisülesannete sooritamisel edukamad kui need, kes oma võimekusse ei usu ning kellel domineerib väline lugemismotivatsioon (Becker, McElvany, \& Kortenbruck, 2010; Gottfried, 1990; Guthrie et al., 2000). Seejuures on oluline märkida, et motivatsioon ei mõjuta lugemisoskuse arengut otseselt, vaid õpikäitumise kaudu. On leitud, et ennast kehva lugejana tajuvad õpilased hakkavad hoiduma pingutust nõudvatest lugemisülesannetest, lükkavad ülesannete täitmist edasi või loobuvad sellest üldse, seevastu õpilased, kes oma võimetesse usuvad, on lugemisülesannete sooritamisel aktiivsed ja püsivad, seda ka raskete ja pingutust nõudvate ülesannete puhul (Guthrie et al., 2007; Zimmerman, 2000). Kirjeldatud õpikäitumine, st vältivate või meisterlikkusele suunatud 
õpistrateegiate rakendamine, avaldab laste lugemisoskusele vastavalt kas negatiivset või positiivset mõju juba esimeses klassis (Aunola et al., 2002; Lepola, Niemi, Kuikka, \& Hannula, 2005).

\section{Õpetajate kasvatustegevused ning nende seosed õpilaste akadeemiliste oskuste ja motivatsiooniga}

Õpetajad erinevad selle poolest, mida ja kuidas nad tundides teevad. Meie kasutasime siinses uurimuses varase lapseea klassiruumi vaatluse mõõdikut (Early Childhood Classroom Observation Measure - ECCOM; Lerkkanen et al., 2012a; Stipek \& Byler, 2005), millega hinnatakse kolme tüüpi kasvatustegevusi: lapsekeskseid, õpetajakeskseid ja laps-domineerivaid (Daniels \& Shumow, 2003; Lerkkanen et al., 2012a; Stipek \& Byler, 2005). Nende teoreetiliseks aluseks on vastavalt konstruktivism, biheiviorism ja küpsemise käsitlus (Daniels \& Shumow, 2003). Õpetajate tegevused hõlmavad kolme laiemat valdkonda: klassitegevuse juhtimist, sotsiaalemotsionaalset toetamist ning õpetamist/juhendamist (Hamre \& Pianta, 2010; Stipek \& Byler, 2005). Tegevused erinevad ka selle poolest, kuivõrd rahuldatakse laste põhivajadusi - kompetentsus-, autonoomia- ja seotusvajadust (Deci \& Ryan, 2000) - ning kuivõrd toetatakse laste akadeemilist, motivatsioonilist ja sotsiaal-emotsionaalset arengut. Reaalselt kasutavad õpetajad kõiki kolme tüüpi tegevusi. Nende osakaal sõltub õpisisust ja lastest, kuid ka õpetaja uskumustest, oskustest ja teadmistest (Stipek \& Byler, 2004).

Lapsekesksed tegevused eeldavad laste aktiivset osalust õppimisprotsessis ning toetavad nende akadeemilist, sotsiaalset ja motivatsioonilist arengut (McCombs, 2010; Stipek \& Byler, 2004). Juhendamisel eeldatakse, et lapsed konstrueerivad teadmisi, toetudes varasematele teadmistele, oskustele ja kogemustele, ning väärtustatakse laste huvi (McCombs, 2010). Õpetajad teevad rühmatöid ja korraldavad arutelusid, nad nõuavad küll faktide ja reeglite teadmist, kuid esitavad ka arutlemist nõudvaid küsimusi (McCombs, 2010; Wentzel, 2010). Lastele antakse võimalusi otsuseid langetada, neid julgustatakse tegutsema, neile antakse individuaalset tagasisidet, lisaks toetatakse oskuste saavutamist ja ülesandele suunatud õpikäitumist (Wentzel, 2010). Distsipliini hoidmise eesmärgil arutletakse klassireeglite üle, õpetaja aitab lastel lahendada konflikte, kasutades neid ka võimalusena arutleda nende tekkepõhjuste ja vältimisviiside üle, st õpetaja loob turvalise klassikeskkonna (Wentzel, 2010).

Õpetajakeskseid tegevusi iseloomustab õpetaja domineerimine ja laste tegevuste sage kontrollimine. Õpilasi käsitletakse passiivsete vastuvõtjatena, kelle õppimise edukuse eest vastutab õpetaja (Gettinger \& 
Kohler, 2011). Rõhutatakse, et enne keerukamate probleemide juurde asumist tuleb omandada põhioskused (nt enne teksti mõistmise ülesannete andmist peaksid õpilased oskama sõnu korrektselt lugeda). Õpetajad räägivad ise palju ning treenivad laste põhioskusi. Õpetajad annavad küll pidevat ópitavaga seotud tagasisidet, kontrollivad ülesannete lahendamise käiku, kuid emotsionaalselt toetavad lapsi vähe (Gettinger \& Kohler, 2011). Laste huvidele tähelepanu ei pöörata. Distsiplineerimisel nõutakse ranget reeglite järgimist, kuid nende sisu üle arutletakse vähe.

Erinevus kahe eelneva ning laps-domineerivate tegevuste vahel seisneb eelkõige õpetaja pakutavas juhendamise, distsiplineerimise ja toetamise määras. Nimelt iseloomustab laps-domineerivaid tegevusi vabaduse andmine (n-ö loomuliku arengu võimaldamine) ilma otsese suunamise ja toetuseta. Õpetajad on pigem passiivsed kõrvaltvaatajad, kes toetavad ja kontrollivad vaid siis, kui lapsed seda küsivad või kui konfliktid on väga suureks paisunud (Lerkkanen et al., 2012a). Seega ei soodusta niisugused tegevused otseselt ei õpilaste akadeemilist, sotsiaalset ega motivatsioonilist arengut.

See, mis tegevused toetavad laste arengut parimal viisil, on seotud nii laste vanuse, olemasolevate teadmiste, oskuste ja motivatsiooniga kui ka konkreetsete õpiülesannete ja eesmärkidega. Näiteks on leitud, et lapse- ja õpetajakesksed tegevused toetavad laste lugemistehniliste oskuste arengut algklassides, sest neid treenitakse ning lapsed saavad detailset tagasisidet õpitava kohta (Connor et al., 2009b; Connor, Morrison, \& Katch, 2004). Lapsekesksete tegevuste korral toetab ópetaja lapsi emotsionaalselt, tekitades keskkonna, kus lapsed julgevad proovida ja ei karda eksimist, ning nii arenevad ka oskused (Perry, Donohue, \& Weinstein, 2007). Kuid ainult lapsekeskne kasvatusviis toetab laiapõhjalist arengut, motivatsiooni ja huvi (Lerkkanen et al., 2012b; Stipek et al., 1998), samas kui õpetajakesksete tegevustega klassides on täheldatud õpilaste väiksemat õpimotivatsiooni ja püsimatust (Guthrie et al., 2000; Stipek et al., 1998). Vähem on uuritud laps-domineerivate tegevuste mõju laste arengule. Need üksikud uuringud on näidanud, et liiga suur vabadus ja õpetajate vähene tugi algklassides pärsivad nii akadeemiliste kui ka sotsiaalsete oskuste arengut (Walker, 2008).

\section{Töö eesmärk ja hüpoteesid}

Töö eesmärk oli analüüsida, kas ja kuidas erinevad esimese klassi laste lugemisoskus ja motivatsioon kolme tüüpi kasvatusstiiliga - lapsekeskse, õpetajakeskse ja laps-domineeriva stiiliga - õpetajate klassides. Töös püstitasime järgmised hüpoteesid. 
1. Õpetajate kasvatusstiili ja õpilaste lugemistehniliste oskuste seoste kohta püstitasime kaks alternatiivset hüpoteesi. Esiteks oletasime (hüpotees 1a), et laste lugemistehniliste oskustega seostub positiivselt õpetajakeskne kasvatusstiil, sest selle puhul paneb õpetaja suurt rõhku õpilaste mehaaniliste oskuste, st lugemise ladususe ja õigsuse treenimisele (Gettinger \& Kohler, 2011); lapsekeskse kasvatusstiili seosed laste oskustega on nõrgemad, sest õpetaja ei pööra õpetamisel põhitähelepanu niivõrd lugemistehniliste oskuste harjutamisele kui mõistmisele (Stipek \& Byler, 2004); laps-domineeriv kasvatusstiil seostub laste oskustega negatiivselt (Walker, 2008). Alternatiivselt oletasime (hüpotees $1 \mathrm{~b}$ ), et laste lugemistehniliste oskustega seostub positiivselt nii lapse- kui ka õpetajakeskne kasvatusstiil: kui õpetajakesksed tegevused suunavad harjutama, siis lapsekesksete tegevuste kaudu toetab õpetaja laste motivatsiooni, mis võib omakorda suunata lapsi rohkem pingutama (Connor et al., 2004, 2009b; Gettinger \& Kohler, 2011; Perry et al., 2007); laps-domineeriv kasvatusstiil seostub laste oskuste arenguga negatiivselt (Walker, 2008).

2. Oletasime (hüpotees 2), et õpilaste loetu mõistmisega on positiivselt seotud lapsekeskne kasvatusstiil, mille puhul õpetaja pöörab suurt tähelepanu laste mõistmisoskuse arendamisele üldiselt ning julgustab neid pingutama (McCombs, 2010; Stipek \& Byler, 2004; Wentzel, 2010). Laste loetu mõistmist toetab vähem õpetajakeskne stiil, mille puhul on esikohal eelkõige põhioskuste mehaaniline treenimine (Stipek \& Byler, 2004). Laps-domineeriv kasvatusstiil seostub laste mõistmisoskuste arenguga negatiivselt (Walker, 2008).

3. Oletasime (hüpotees 3), et laste motivatsiooniga, st lugemishuvi ja tajutud võimekusega, seostub positiivselt vaid lapsekeskne kasvatusstiil, mille korral õpetaja väärtustab laste huvisid ning julgustab ja toetab lapsi õppetöös emotsionaalselt. Õpetajakeskne ja laps-domineeriv stiil seostuvad laste motivatsiooniga negatiivselt, sest oppetaja emotsionaalne tugi ja laste huvidega arvestamine on vähene (McCombs, 2010; Stipek \& Byler, 2004; Wentzel, 2010).

\section{Meetod}

\section{Valim}

Üheaastases pikiuuringus osales 440 esimeste klasside õpilast ja nende õpetajad. Laste arv varieerub analüüsides, sest osa õpilastest ei osalenud testimisel mõlemal mõõtmiskorral koolist puudumise tõttu või sooritasid 
testid ühel mõõtmiskorral osaliselt (nt õpilane osales klassitestis, kuid ei teinud individuaaltesti või vastupidi). Osalenud laste arv on esitatud iga analüüsi juures. Uuringu alguses olid õpilased 6-8-aastased (keskmine vanus 1 . septembri seisuga 88,12 kuud, $S D=3,89$ ). Valim koosnes $51 \%$ tüdrukutest ja $49 \%$ poistest. $94 \%$ õpilastest oli kodune keel eesti keel, 6\% lastest olid pärit vene- või kakskeelsetest peredest. Muukeelsed lapsed jaotusid klasside vahel ühtlaselt, ühes klassis oli kuni kolm muukeelset õpilast. Õpilased käisid seitsmes Eesti koolis, millest kuus asusid linnas ja üks makonnas. Klasse oli kokku 21, klassi keskmine suurus oli 23,48 õpilast $(S D=2,46)$. Kõik valimisse kuulunud õpilased õppisid põhikooli riikliku oppekava (Vabariigi Valitsus, 2010) alusel.

Õpetajate valim koosnes 21 naissoost klassiõpetajast vanuses 25-57 aastat $(M=40,71, S D=7,14) .5$ õpetajal oli töökogemust õpetajana alla 1 aasta, 3 õpetajal 6-10 aastat, 1 õpetajal 11-15 aastat ning 12 õpetajal üle 15 aasta. Kõigil õpetajatel oli pedagoogiline kõrgharidus: 3 õpetajal oli rakenduslik ja 18 õpetajal magistritasemel kõrgharidus.

\section{Protseduur}

Kasutatavad andmed pärinevad laiemast kaheaastasest uurimisprojektist. Esmalt võtsime ühendust koolide direktoritega, keda teavitasime uuringu eesmärkidest, ning kutsusime nende koole projektis osalema. Kui direktorid olid andnud nõusoleku, teavitasime klassiõpetajaid, kes võtsid ühendust oma klassi laste vanematega. Uuringus osalesid ainult need lapsed, kelle vanemad olid selleks andnud informeeritud nõusoleku (93\% esialgsest valimist).

Esimese klassi alguses (september-oktoober) viidi esmalt läbi rühmatestid klassiga ühiselt ning seejärel kohe individuaalsed intervjuud. Esimese klassi lõpus (aprill-mai) tehti samuti rühmatestid, millele järgnesid intervjuud. Rühmatestimine toimus mõlemal mõõtmiskorral kahe klassitunni jooksul, intervjuus kulus lapsele 3-5 minutit. Kõik testid viisid läbi uuringu assistendid. Klassi lõpus täitsid õpetajad ankeedid, mis sisaldasid küsimusi taustandmete (õpetaja vanuse, tööstaaži, hariduse) kohta.

Esimese klassi keskel (veebruar-märts) viisid vaatlejate paarid läbi klassitundide vaatlused, järgides ECCOMi manuaalis kirjeldatud protseduure (Stipek \& Byler, 2005). Kõigil viiel vaatlejal (neist kahel magistrija kahel doktorikraad haridusteadustes, ühel magistrikraad psühholoogias) oli varasem vaatlemiskogemus sama mõõdikuga. Kõik vaatlused algasid koolipäeva alguses ja kestsid kolm koolitundi (st 135 minutit). Alati vaadeldi emakeele- ja matemaatikatunde, kolmas tund olenes tunni- 
plaanist ning võis olla emakeel, matemaatika, muusika, kunst või käsitöö. Vaatlejad tegid tundide ajal kirjalikke märkmeid. Pärast vaatlust koostasid mõlemad vaatlejad oma hinnangud iseseisvalt.

\section{Mõõdikud}

Lugemistehnilised oskused. Lugemistehniliste oskuste hindamiseks esimese klassi alguses ja lõpus kasutasime kahte mõõdikut: sõnaloendi lugemise testi ja sõnade äratundmise testi.

Sõnaloendi lugemise testi aluseks on võetud Soome standardiseeritud testipaketi „Lukilasse” (Häyrinen, Serenius-Sirve, \& Korkman, 1999) üks alatest, eestikeelse testi on koostanud Piret Soodla ja Inna Marats. Test koosnes kolme veergu paigutatud 90 sõnast, mis olid järjestatud sõna häälik- ja silbistruktuuri keerukusastme tõusu põhimõttel: testi esimesed sõnad olid lihtsa struktuuriga ühe- ja kahesilbilised sõnad (nt ema, talu, puru), järgmised aga pikemad ja keerulisema silbistruktuuriga sõnad ning võõrsõnad (nt kaubanduskeskus, aritmeetika). Kõik testisõnad olid esitatud väikestes trükitähtedes. Test tehti individuaalselt. Ülesande sooritusele eelnes täpne juhis. Õpilane pidi 45 sekundi jooksul sõnu võimalikult kiiresti häälega lugema, seejuures oli ta teadlik ajafaktorist. Testi abil hindasime õpilaste sõnalugemise sujuvust, mida näitas õigesti loetud sõnade arv etteantud ajalimiidi jooksul (maksimaalselt 90).

Sõnade äratundmise test on koostatud Soome testipaketi „Alaasteen lukutesti” (Lindeman, 1998) ühe alatesti eeskujul (koostaja Piret Soodla). Test koosneb 80 pildist ja 320 sõnast. Iga pildi juures on neli sarnase hälikkoostisega sõna, millest üks vastab pildile (nt pilt 'tigu'- sõnad tegu, tibu, tigu, tina). Piltidel kujutatud objektide äratundmist me ei kontrollinud, kuid varasem uurimus (Soodla, Vija, \& Pajusalu, 2013) näitab, et piltidel kujutatu on algklassiõpilastele arusaadav. Testisõnad olid järjestatud häälik- ja silbistruktuuri keerukusastme tõusu põhimõttel: esimesed sõnad on lihtsa struktuuriga (nt $k u u, t i b u$ ), testi edenedes muutusid sõnad pikemaks ja struktuurilt keerukamaks (nt võtmed, kummirõngas, dinosaurus). Klassi alguses olid testisõnad suurtes trükitähtedes, klassi lõpus väikestes trükitähtedes. Lapsi testiti rühmas, ülesande sooritusele eelnes selgitus ning neli harjutusülesannet, mis tehti läbi kõigi lastega ühiselt. Ülesanne oli kahe minuti jooksul ühendada joone abil võimalikult palju pilte sobiva sõnaga, seejuures olid lapsed teadlikud ajafaktorist. Testi sooritust näitas õigesti ühendatud sõnade hulk (maksimaalselt 80). Testiga hindasime sõnade lugemise (dekodeerimise ja äratundmise) kiirust vaiksel lugemisel. 
Sõnaloendi lugemise testi ja sõnade äratundmise testi tulemused korreleerusid tugevalt nii esimesel $(r=0,83, p<0,001)$ kui ka teisel mõõtmiskorral $(r=0,76, p<0,001)$, mistõttu lugemistehniliste oskuste koondskoori saamiseks liitsime testide tulemused. Nende testide sobivusele lugemistehniliste oskuste näitajana osutavad sõnade äratundmise testi tugevad seosed 1.-3. klassis teksti lugemise ladususega $(0,60<r 0,70)$ ning mõõdukad kuni tugevad seosed õpetajate hinnangutega laste lugemistehnilistele oskustele $\left(0,40<r_{s}<0,63\right)$ (Mõttus, 2013). Sõnalugemistestide sobivust lugemistehniliste oskuste hindamisel toetavad ka teistes keeltes tehtud uuringud, kus on leitud tugevaid korrelatsioone sõna- ja tekstitasandi lugemistehniliste oskuste vahel (nt Georgiou, Parrila, \& Papadopoulos, 2008; Landerl \& Wimmer, 2008; Torppa, Eklund, van Bergen, \& Lyytinen, 2011).

Loetu mõistmine. Loetu mõistmise testi (Lindeman, 1998, tõlkija Maigi Vija) tegime teisel mõõtmiskorral rühmas. Test koosneb teabetekstist (150 sõna, väiketähed) ja 12st teksti kohta esitatud ülesandest, millest 11 on valikvastustega küsimused ning ühes tuleb järjestada olemasolevaid infoüksusi teksti järgi. Ülesannetega mõõdetakse tekstis otseselt sisalduva teabe mõistmist (9 ülesannet) ja järelduste tegemist (3 ülesannet). Õpilastel tuli iseseisvalt läbi lugeda tekst ja vastata seejärel küsimustele. Tekst oli küsimustele vastamise ajal lapsele kättesaadav ning ajalist piirangut testi sooritamiseks ei olnud. Iga õige vastuse eest sai laps punkti (maksimaalselt 12 punkti). Testi Cronbachi alfa on 0,87 .

Lugemismotivatsioon. Mõlemal mõõtmiskorral hindasime õpilaste lugemishuvi ja tajutud lugemisvõimekust. Hindamise viisime läbi rühmas.

Lugemishuvi kohta luges testija lastele eraldi ette kolm väidet („Lugeda on tore”, „Mulle meeldib koolis lugeda”, „Mulle meeldib kodus lugeda”) ning palus lapsel hinnata, kas väide käib tema kohta (ringitada ,jah”) või ei käi (ringitada „ei”). Positiivsed vastused andsid 1 punkti, negatiivsed vastused 0 punkti. Maksimaalne punktisumma oli 3. Lugemishuvi hindamise protseduur oli kahel mõõtmiskorral samasugune. Mõõdiku Cronbachi alfad olid klassi alguse ja lõpu mõõtmiskordadel vastavalt 0,76 ja 0,82 .

Tajutud lugemisvõimekust hindasime kahel mõõtmiskorral mõnevõrra erinevalt. Klassi alguses palus testija lastel hinnata kolmepallisel skaalal oma lugemisvõimekust („Hinda, kuidas sul läheb lugemises praegu”). Õpilastel tuli ära värvida vastav arv ringe $(1=$ halvasti, $2=$ keskmiselt, 3 = hästi). Maksimaalne punktisumma oli 3. Teisel mõõtmiskorral luges 
testija lastele ette eraldi kolm väidet („Ma loen hästi”, „Ma olen hea lugeja”, „Mul läheb lugemises hästi”) ning palus hinnata, kas väide käib lapse kohta (ringitada „jah”) või ei käi (ringitada „ei”). Positiivsed vastused andsid 1 punkti, negatiivsed vastused 0 punkti, kokku oli võimalik saada 3 punkti. Mõõdiku Cronbachi alfa teisel mõõtmiskorral oli 0,97.

Oppetajate kasvatustegevused. Kasvatustegevusi vaadeldi varase lapseea klassiruumi vaatluse mõõdiku ECCOM abil (Stipek \& Byler, 2005). Kasvatustegevusi hinnati kolmel skaalal: lapsekesksed, õpetajakesksed ja laps-domineerivad tegevused. Iga tüüpi hinnati 14 konkreetse tegevuse kirjelduse kaudu (st kokku $3 \times 14$ kirjeldust). Tegevused haarasid kolme olulist valdkonda: juhtimist, toetamist ja õpetamist. Kirjeldused varieerusid olenevalt kasvatustegevuse tüübist (vt lisa 1). Hinnangud anti viiepallisel skaalal, mis põhines sellel, kui sagedasti tegevust klassis täheldati ( $1=$ tegevusi on väga harva, st $0-20 \%$ ajast; $5=$ tegevused domineerivad, st $80-100 \%$ ajast). Iga õpetaja sai kolm - lapsekesksete, õpetajakesksete ja laps-domineerivate tegevuste - skoori.

Hindajatevahelise reliaabluse arvutasime klassisisese korrelatsiooni (intra-class correlation ICC) kaudu. Kasutasime kahesuunalist segaefektimudelit (two-way mixed effect model; mõõdetav on fikseeritud, hindajad juhuslikud) koos absoluutse kooskõlaga ja keskmise ICC väärtusega. McGraw' ja Wongi (1996) kohaselt sobib see meetod hästi siis, kui hindajad on klassiti erinevad ja hinnanguid antakse pideval skaalal. ICCd olid statistiliselt olulised $(p<0,001)$ kõigi skaalade korral (lapsekeskse, õpetajakeskse ja laps-domineeriva skaala korral vastavalt $0,91,0,84$ ja $0,97)$. Iga $3 \times 14$ kirjelduse kohta arvutasime kahe hindaja keskmise tulemuse. Nende alusel saime iga skaala keskmise. Skaalade sisereliaablused olid väga head (Cronbachi alfa $>0,91$ ).

Andmeanalüüs. Andmeanalüüsil kombineerisime variaablikeskseid meetodeid (ühefaktoriline dispersioonanalüüs) indiviidikesksete meetoditega (konfiguraalne sagedusanalüüs, CFA; vt Bergman \& El-Khouri, 2002). See tähendab, et uurisime üldisi seoseid õpetajate kasvatusstiilide ning laste oskuste ja motivatsiooni vahel, kuid keskendusime ka oskuste või motivatsiooni taseme poolest sarnaste õpilaste alarühmadele. CFA tulemusena eristusid mingite tunnuste kombinatsioonide põhjal tüübid (indiviidide rühmad, mille esinemissagedus on oodatust oluliselt suurem) ja antitüübid (indiviidide rühmad, mille esinemissagedus on oodatust oluliselt väiksem). Selline analüüs võimaldas uurida, kuidas jaotusid erinevaid kasvatustegevusi praktiseerivate õpetajate klasside õpilased 
lugemistehniliste oskuste, loetu mõistmise, lugemishuvi ning tajutud võimekuse alusel. CFA jaoks kategoriseerisime õpilaste pidevad andmed (lugemistehnilised oskused, loetu mõistmine, lugemishuvi ja tajutud lugemisvõimekus) kolme kategooriasse. Lugemistehniliste oskuste ja loetu mõistmise valdkonnas võtsime kategoriseerimise lähtekohaks kvartiilid: eristasime kehvade tulemustega õpilasi (tulemus alla alumise kvartiili), keskmiste tulemustega õpilasi ja heade tulemustega õpilasi (tulemus üle ülemise kvartiili). Lugemishuvi ja tajutud võimekuse skooride alusel jaotasime õpilased järgmiselt: väikese lugemishuviga / tajutud võimekusega õpilased (0-1 punkti), keskmise lugemishuviga / tajutud võimekusega õpilased (2 punkti) ja suure lugemishuviga / tajutud võimekusega õpilased (3 punkti). CFA tegime paketiga Sleipner 2.1 (Bergman \& El-Khouri, 2002). Dispersioonanalüüsil kasutasime efekti suuruse ühikuna osalist eta ruutu $\left(\mathrm{n}_{\mathrm{p}}^{2}\right)$ ja post hoc-testina Bonferroni testi. CFAs kasutasime binominaalset testi ja vastavat tõenäosust.

\section{Tulemused}

\section{Kirjeldav statistika}

Laste lugemisoskused ja -motivatsioon esimese klassi alguses ja lõpus. Laste tulemused lugemistehnikas, loetu mõistmises, lugemishuvis ja tajutud võimekuses on esitatud tabelis 1.

Tabel 1. Õpilaste tulemused lugemistehnikas, loetu mõistmises, lugemishuvis ja tajutud võimekuses esimese klassi alguses ja lõpus

\begin{tabular}{l|c|r|r|r|c}
\hline Lugemise aspekt & $\boldsymbol{N}$ & Min & Max & $\boldsymbol{M}$ & \multicolumn{1}{c|}{$\boldsymbol{S} D$} \\
\hline Lugemistehnika (1) & 437 & 1 & 100 & 30,23 & 18,00 \\
\hline Lugemistehnika (2) & 414 & 15 & 114 & 43,71 & 17,25 \\
\hline Loetu mõistmine (2) & 414 & 0 & 12 & 6,09 & 2,90 \\
\hline Lugemishuvi (1) & 434 & 0 & 3 & 2,57 & 0,74 \\
\hline Lugemishuvi (2) & 408 & 0 & 3 & 2,37 & 0,91 \\
\hline Tajutud võimekus (1) & 440 & 1 & 3 & 2,60 & 0,62 \\
\hline Tajutud võimekus (2) & 406 & 0 & 3 & 2,46 & 1,01 \\
\hline
\end{tabular}

Märkus. 1 = esimene mõõtmiskord, 2 = teine mõõtmiskord. 


\section{Õpetajate kasvatusstiilid ja õpilaste tulemused}

Õpetajate kasvatusstiilid ja laste lugemistehnilised oskused. Esmalt kontrollisime laste lugemistehniliste oskuste võimalikke erinevusi eri kasvatusstiilidega õpetajate klasside õpilaste vahel esimesel mõõtmiskorral. Selleks tegime dispersioonanalüüsi, kus sõltumatu tunnus oli õpetaja klaster ja sõltuv tunnus õpilase lugemistehniliste oskuste koondskoor. Analüüs näitas, et eri kasvatusstiilidega klasside õpilaste lugemistehnilised oskused oluliselt ei erinenud: lapsekeskse kasvatusstiiliga klassides $M=31,74$, $S D=17,86$, õpetajakeskse kasvatusstiiliga klassides $M=28,99, S D=18,72$, laps-domineeriva kasvatusstiiliga klassides $M=29,48, S D=17,27 ; F(2$, $434)=1,07, p=0,35, \mathrm{n}_{\mathrm{p}}{ }^{2}=0,01$. Lisaks näitas CFA, et erineva lugemisoskuse tasemega õpilased jaotusid klastrite vahel ühtlaselt (tabel 2).

Tabel 2. CFA tulemused: seosed õpetajate kasvatusstiilide ja õpilaste lugemistehniliste oskuste vahel esimese klassi alguses ja lõpus

\begin{tabular}{|c|c|c|c|c|c|c|c|}
\hline \multirow{2}{*}{$\begin{array}{l}\text { Kasvatus- } \\
\text { tegevuste } \\
\text { klaster }\end{array}$} & \multirow{2}{*}{$\begin{array}{l}\text { Lugemis- } \\
\text { tehniliste } \\
\text { oskuste tase }\end{array}$} & \multicolumn{3}{|c|}{$\begin{array}{c}\text { Klassi algus } \\
N=437\end{array}$} & \multicolumn{3}{|c|}{$\begin{array}{l}\text { Klassi lõpp } \\
N=414\end{array}$} \\
\hline & & $f_{o}$ & $f_{e}$ & $p$ & $f_{o}$ & $f_{e}$ & $p$ \\
\hline \multirow{3}{*}{ Lapsekeskne } & Madal & 28 & 32,81 & 0,22 & 17 & 30,47 & 0,01 \\
\hline & Keskmine & 110 & 108,14 & 0,44 & 117 & 107,06 & 0,15 \\
\hline & Kõrge & 39 & 36,05 & 0,33 & 32 & 28,47 & 0,27 \\
\hline \multirow{3}{*}{ Õpetajakeskne } & Madal & 32 & 26,88 & 0,18 & 34 & 26,25 & 0,08 \\
\hline & Keskmine & 86 & 88,59 & 0,41 & 87 & 92,22 & 0,29 \\
\hline & Kõrge & 27 & 29,53 & 0,36 & 22 & 24,52 & 0,35 \\
\hline \multirow{3}{*}{$\begin{array}{l}\text { Laps- } \\
\text { domineeriv }\end{array}$} & Madal & 21 & 21,32 & 0,53 & 25 & 19,28 & 0,11 \\
\hline & Keskmine & 71 & 70,26 & 0,48 & 63 & 67,72 & 0,29 \\
\hline & Kõrge & 23 & 23,42 & 0,52 & 17 & 18,01 & 0,47 \\
\hline
\end{tabular}

Märkus. $f_{o}=$ vaadeldud sagedus, $f_{e}=$ oodatud sagedus. Antitüübid on esitatud kaldkirjas. 
Teiseks uurisime eri kasvatusstiilidega õpetajate klasside õpilaste lugemistehnilisi oskusi klassi lõpus. Dispersioonanalüüs näitas olulisi erinevusi lugemisoskuses eri klastrite vahel: lapsekeskse kasvatusstiiliga klassides olid laste tulemused paremad $(M=46,54, S D=17,40)$ kui õpetajakeskse $(M=41,71, S D=17,12)$ ja laps-domineeriva kasvatusstiiliga klassides $(M=41,97, S D=16,73), F(2,411)=3,78, p=0,02, \mathrm{y}_{\mathrm{p}}{ }^{2}=0,02$. Post hoctest näitas, et lapsekeskse kasvatusstiiliga klasside õpilaste tulemused erinesid nii laps-domineeriva $(p=0,04)$ kui ka õpetajakeskse kasvatusstiiliga klasside õpilaste tulemustest (statistiliselt piiripealne olulisus, $p=0,10$ ). CFA tulemusel selgus (tabel 2), et kui lapsekeskse kasvatusstiiliga klastris oli nõrkade lugemistehniliste oskustega lapsi oodatud sagedusest vähem (antitüüp), siis õpetajakeskse kasvatusstiiliga klassides ilmnes vastupidine tendents: kehvi lugejaid oli neis oodatust mõnevõrra rohkem (statistiliselt piiripealne olulisus). Keskmiste ja heade lugemistehniliste oskustega laste vaadeldud ja oodatavad sagedused ei erinenud statistiliselt olulisel määral mitte üheski klastris.

Õpetajate kasvatusstiilid ja õpilaste loetu mõistmine. Kõigepealt võrdlesime eri kasvatusstiiliga õpetajate klasside õpilaste loetu mõistmise oskusi esimese klassi lõpus dispersioonanalüüsiga, kus sõltumatu tunnus oli õpetaja klaster ja sõltuv tunnus lapse loetu mõistmise skoor. Lapsekeskse kasvatusstiiliga klassides oli testitulemus kõige parem $(M=6,87$, $S D=2,63)$, järgnesid laps-domineeriva $(M=5,63, S D=2,95)$ ja õpetajakeskse kasvatusstiiliga klasside õpilaste tulemused $(M=5,50, S D=2,98)$. Erinevused õpilaste loetu mõistmise tulemustes olid statistiliselt olulised, $F(2,411)=10,88, p<0,001, \mathrm{n}_{\mathrm{p}}^{2}=0,05$. Post hoc-test näitas, et lapsekeskse kasvatusstiiliga klasside õpilaste tulemused olid nii õpetajakeskse $(p<0,001)$ kui ka laps-domineeriva $(p=0,001)$ kasvatusstiiliga klasside laste tulemustest oluliselt paremad. Viimased omavahel ei erinenud.

CFA võimaldas täpsustada dispersioonanalüüsi tulemusi (tabel 3). Selgus, et lapsekeskse kasvatusstiiliga klassides oli hea loetu mõistmise oskusega õpilasi oodatud sagedusest oluliselt rohkem (tüüp) ja kehvi mõistjaid oodatud sagedusest oluliselt vähem (antitüüp). Õpetajakeskse ja laps-domineeriva kasvatusstiiliga õpetajate klassides ilmnes vastupidine tendents: häid tekstimõistjaid oli oodatud sagedusest mõnevõrra vähem (õpetajakeskse kasvatusstiiliga klastris statistiliselt piiripealne olulisus), madala tekstimõistmisoskuste tasemega lapsi esines aga sageli (õpetajakeskse kasvatusstiiliga klassides tüüp, laps-domineeriva stiiliga klassides piiripealne olulisus). Seega võib öelda, et kui lapsekeskse kasvatusstiiliga õpetajate klassides ilmnes, et õpilased mõistavad loetut paremini, siis 
ópetajakeskne ja laps-domineeriv kasvatusstiil seostusid õpilaste loetu mõistmisega negatiivselt.

Tabel 3. CFA tulemused: seosed õpetajate kasvatusstiilide ja õpilaste loetu mõistmise vahel esimese klassi lõpus

\begin{tabular}{l|l|c|c|c}
\hline $\begin{array}{l}\text { Kasvatustegevuste } \\
\text { klaster }\end{array}$ & \multicolumn{1}{|c|}{ Loetu mõistmise tase } & $\boldsymbol{f}_{\boldsymbol{o}}$ & $\boldsymbol{f}_{\boldsymbol{e}}$ & $\boldsymbol{p}$ \\
\hline \multirow{2}{*}{ Lapsekeskne } & Madal & 16 & 35,90 & $<0,001$ \\
& Keskmine & 103 & 96,00 & 0,22 \\
& Kõrge & $\mathbf{4 8}$ & $\mathbf{3 5 , 0 9}$ & $\mathbf{0 , 0 2}$ \\
\hline \multirow{2}{*}{ Õpetajakeskne } & Madal & $\mathbf{4 4}$ & $\mathbf{3 0 , 9 6}$ & $\mathbf{0 , 0 1}$ \\
& Keskmine & 77 & 82,78 & 0,26 \\
& Kõrge & 23 & 30,26 & 0,10 \\
\hline \multirow{2}{*}{ Laps-domineeriv } & Madal & 29 & 22,14 & 0,09 \\
& Keskmine & 58 & 59,21 & 0,47 \\
& Kõrge & 16 & 21,64 & 0,13 \\
\hline
\end{tabular}

Märkus. $N=414, f_{o}=$ vaadeldud sagedus, $f_{e}=$ oodatud sagedus. Tüübid on esitatud poolpaksus kirjas, antitüübid kaldkirjas.

Õpetajate kasvatusstiilid ja õpilaste lugemismotivatsioon. Kõigepealt kontrollisime, kas klassi alguses esines lugemishuvis erinevusi eri kasvatusstiilidega ópetajate klasside õpilaste vahel. Selleks tegime dispersioonanalüüsi, kus sõltumatu tunnus oli õpetaja klaster ja sõltuv tunnus õpilase lugemishuvi skoor. Lugemishuvi keskmised skoorid olid järgmised: lapsekeskse kasvatusstiiliga klassides $M=2,66(S D=0,66)$, oppetajakeskse stiiliga klassides $M=2,55(S D=0,58)$ ja laps-domineeriva stiiliga klassides $M=2,49(S D=0,41)$. Statistilisi erinevusi eri klastritesse kuuluvate õpilaste lugemishuvis ei esinenud, $F(2,431)=1,94, p=0,15, \mathrm{n}_{\mathrm{p}}^{2}=0,01$. CFA näitas, et erineva lugemishuvi tasemega õpilased jaotusid klastrite vahel ühtlaselt (tabel 4).

Teiseks uurisime, kuidas seostusid ópetajate kasvatusstiilid õpilaste lugemishuviga klassi lõpus. Lugemishuvi keskmised skoorid olid lapsekeskse kasvatusstiiliga klassides $M=2,51(S D=0,81)$, õpetajakeskse kasvatusstiiliga klassides $M=2,39(S D=0,87)$ ja laps-domineeriva kasvatusstiiliga klassides $M=2,12(S D=1,06)$. Eri kasvatusstiiliga klasside õpilaste lugemishuvi erines oluliselt, $F(2,405)=6,05, p=0,003$, $\mathrm{y}_{\mathrm{p}}{ }^{2}=0,03$, olles laps-domineeriva $(p=0,002)$ ja õpetajakeskse stiiliga 
$(p=0,05)$ klasside laste tulemustega võrreldes oluliselt suurem just lapsekeskse kasvatusstiiliga klassides. CFA näitas, kuidas jaotusid väikese, keskmise ja suure lugemishuviga lapsed klastrite vahel (tabel 4). Selgus, et laps-domineeriva kasvatusstiiliga õpetajate klassides oli suhteliselt palju väikese lugemishuviga õpilasi (tüüp) ning vähe suure lugemishuviga lapsi (statistiliselt piiripealne olulisus). Seevastu lapsekeskse kasvatusstiiliga õpetajate klassides oli suhteliselt vähe väikese lugemishuviga õpilasi (statistiliselt piiripealne olulisus). Õpetajakeskse kasvatusstiiliga klassides jaotusid erineva lugemishuvi tasemega õpilased juhuslikult.

Tabel 4. CFA tulemused: seosed õpetajate kasvatusstiilide ja õpilaste lugemishuvi vahel esimese klassi alguses ja lõpus

\begin{tabular}{l|l|r|r|r||c|c|c}
\hline \multirow{2}{*}{$\begin{array}{l}\text { Kasvatus- } \\
\text { tegevuste } \\
\text { klaster }\end{array}$} & \multirow{3}{*}{$\begin{array}{l}\text { Lugemishuvi } \\
\text { tase }\end{array}$} & \multicolumn{3}{|c|}{ Klassi algus } & \multicolumn{3}{c}{ Klassi lõpp } \\
\cline { 3 - 8 } & Madal & 10 & 14,83 & 0,13 & 19 & 26,21 & 0,08 \\
\hline \multirow{2}{*}{ Lapsekeskne } & Keskmine & 36 & 38,49 & 0,38 & 35 & 38,91 & 0,29 \\
& Kõrge & 128 & 120,68 & 0,23 & 108 & 96,88 & 0,11 \\
\hline \multirow{2}{*}{ Õpetajakeskne } & Madal & 14 & 12,36 & 0,36 & 20 & 22,97 & 0,31 \\
& Keskmine & 32 & 32,07 & 0,54 & 38 & 34,11 & 0,27 \\
& Kõrge & 99 & 100,56 & 0,46 & 84 & 84,92 & 0,48 \\
\hline \multirow{2}{*}{ Laps- } & Madal & 13 & 9,80 & 0,19 & $\mathbf{2 7}$ & $\mathbf{1 6 , 8 2}$ & $\mathbf{0 , 0 1}$ \\
domineeriv & Keskmine & 28 & 25,44 & 0,33 & 25 & 24,98 & 0,53 \\
& Kõrge & 74 & 79,76 & 0,26 & 52 & 62,20 & 0,09 \\
\hline
\end{tabular}

Märkus. $f_{o}=$ vaadeldud sagedus, $f_{e}=$ oodatud sagedus. Tüübid on esitatud poolpaksus kirjas.

Tajutud lugemisvõimekuse puhul kontrollisime samuti esmalt, kas klassi alguses ilmnes erinevusi eri kasvatusstiilidega õpetajate klasside õpilaste vahel. Tajutud võimekuse keskmised skoorid olid sarnased: lapsekeskse kasvatusstiiliga klassides $M=2,61(S D=0,61)$, õpetajakeskse kasvatusstiiliga klassides $M=2,59(S D=0,63)$ ja laps-domineeriva kasvatusstiiliga klassides $M=2,60(S D=0,62)$. Dispersioonanalüüsist ilmnes, et tajutud võimekuses eri klastrite õpilaste vahel erinevusi ei olnud, $F(2,437)=0,06$, $p=0,94, \mathrm{n}_{\mathrm{p}}^{2}<0,001$. CFA kohaselt jaotusid tajutud võimekuses eri tasemega õpilased klastrite vahel ühtlaselt (tabel 5). 
Klassi lõpus olid õpilaste tajutud võimekuse skoorid järgmised: lapsekeskse kasvatusstiiliga klassides $M=2,52(S D=0,95)$, õpetajakeskse stiiliga klassides $M=2,37(S D=1,10)$ ja laps-domineeriva stiiliga klassides $M=2,47(S D=0,98)$. Olulisi erinevusi õpilaste tajutud võimekuses eri kasvatusstiiliga õpetajate klasside vahel ei esinenud, $F(2,403)=0,91$, $p=0,41, \mathrm{y}_{\mathrm{p}}{ }^{2}=0,01$. CFA tulemused ei toonud samuti esile ühtegi statistiliselt olulist tendentsi erineva tajutud võimekusega õpilaste jaotumises eri kasvatusstiilidega klastrite vahel (tabel 5).

Tabel 5. CFA tulemused: seosed õpetajate kasvatusstiilide ja õpilaste tajutud võimekuse vahel esimese klassi alguses ja lõpus

\begin{tabular}{|c|c|c|c|c|c|c|c|}
\hline \multirow{2}{*}{$\begin{array}{l}\text { Kasvatustege- } \\
\text { vuste klaster }\end{array}$} & \multirow{2}{*}{$\begin{array}{l}\text { Tajutud } \\
\text { võimekuse } \\
\text { tase }\end{array}$} & \multicolumn{3}{|c|}{$\begin{array}{c}\text { Klassi algus } \\
N=429\end{array}$} & \multicolumn{3}{|c|}{$\begin{array}{c}\text { Klassi lõpp } \\
N=408\end{array}$} \\
\hline & & $f_{o}$ & $f_{e}$ & $p$ & $f_{o}$ & $f_{e}$ & $p$ \\
\hline \multirow{3}{*}{ Lapsekeskne } & Madal & 4 & 6,12 & 0,27 & 23 & 26,66 & 0,27 \\
\hline & Keskmine & 66 & 64,86 & 0,46 & 17 & 17,77 & 0,49 \\
\hline & Kõrge & 105 & 104,02 & 0,48 & 124 & 119,57 & 0,33 \\
\hline \multirow{3}{*}{$\begin{array}{l}\text { Õpetaja- } \\
\text { keskne }\end{array}$} & Madal & 5 & 4,97 & 0,55 & 28 & 22,92 & 0,16 \\
\hline & Keskmine & 55 & 52,63 & 0,39 & 13 & 15,28 & 0,33 \\
\hline & Kõrge & 82 & 84,41 & 0,41 & 100 & 102,80 & 0,40 \\
\hline \multirow{3}{*}{$\begin{array}{l}\text { Laps- } \\
\text { domineeriv }\end{array}$} & Madal & 6 & 3,92 & 0,20 & 15 & 16,42 & 0,42 \\
\hline & Keskmine & 38 & 41,51 & 0,32 & 14 & 10,95 & 0,21 \\
\hline & Kõrge & 68 & 66,57 & 0,45 & 72 & 73,64 & 0,45 \\
\hline
\end{tabular}

Märkus. $f_{o}=$ vaadeldud sagedus,$f_{e}=$ oodatud sagedus.

\section{Arutelu}

Uurimuses vaatlesime õpilaste lugemisoskust ja motivatsiooni esimeses klassis ning analüüsisime nende seoseid õpetajate kasvatusstiilidega. Täpsemalt huvitas meid, kas ja kuidas laste lugemistehnilised oskused, loetu mõistmine ning lugemishuvi ja tajutud võimekus erinevad kolme tüüpi kasvatusstiilidega õpetajate klasside õpilastel. Andmeanalüüsil kombineerisime variaablikeskseid meetodeid (dispersioonanalüüs) indiviidikesksetega (CFA), mis võimaldas uurida nii üldisi seoseid uuritavate tegurite vahel kui ka minna analüüsis täpsemaks, keskenduda indiviidile. Tulemused näitasid, et lapsekeskne kasvatusstiil seostus laste lugemis- 
oskuse ja -huviga positiivselt, ópetajakeskne ja laps-domineeriv stiil aga negatiivselt.

Kui lugemistehnilised oskused eri stiilidega õpetajate klassides esimese klassi alguses ei erinenud, siis aasta lõpus olid need lapsekeskse stiiliga õpetajate klassides paremad kui teiste kasvatusstiilidega õpetajate klassides. CFA näitas erinevusi nõrkade lugejate suhtelises esinemissageduses kasvatusstiili klastrite vahel: lapsekeskse stiiliga klassides oli suhteliselt vähe nõrku lugejaid, õpetajakeskse kasvatusstiiliga õpetajate klassides oli neid aga suhteliselt palju. Kuigi osa varasemaid uurimusi on viidanud sellele, et just nõrgad õpilased vajavad konkreetset elementaarsete oskuste õpetamist ja harjutamist, mida pakuvad eelkõige õpetajakesksed meetodid (vt Connor et al., 2004, 2009b; Stipek \& Byler, 2004), siis meie seda ei leidnud. Siinses uurimuses kasutatud analüüsimeetodid ei võimaldanud küll otseselt kirjeldada põhjuslikke seoseid õpetajate kasvatusstiilide ja laste oskuste arengu vahel, kuid tulemused viitavad pigem sellele, et lapsekeskse stiiliga ópetajad, kes julgustavad lapsi, annavad sisulist tagasisidet ja toetavad neid emotsionaalselt (Perry et al., 2007), soodustavad ka tehniliste oskuste õppimist. Tulemused lubavad seega järeldada, et lapsekesksel kasvatusstiilil on soodne mõju neile lastele, kelle lugemistehnilised oskused arenevad aeglasemalt. Nimelt on umbes kolmandik esimese klassi lastest õppeaasta lõpus veel raskustes sõnade ja lausete sujuva kokkulugemisega (Kalev, 2008) ning nad vajavad seetõttu õpetajalt tuge oskuste omandamisel. Siinsete tulemuste alusel võib arvata, et õpetajakeskne kasvatusstiil ei toeta laste oskuste arengut, sest õpetaja arvestab laste individuaalsete vajadustega vähe (st ei kohanda õppetegevusi, ülesandeid ega õppematerjale) ning pakub neile õppimisel vähe emotsionaalset tuge (Perry et al., 2007). Nagu oletasime, seostus lapsdomineeriv kasvatusstiil õpilaste lugemistehniliste oskustega negatiivselt, mis toetab varasemaid tulemusi (Walker, 2008). Laps-domineerivad õpetajad annavad lastele suure vabaduse, väärtustades nende vaba tegevust. Esimeste klasside ning nõrkade oskuste ja teadmistega õpilased vajavad ilmselt rohkem õpetaja toetust.

Samamoodi ja kooskõlas teise hüpoteesiga seostus õpilaste loetu mõistmisega positiivselt lapsekeskne kasvatusstiil. Valdavalt lapsekeskseid kasvatustegevusi praktiseerivate õpetajate klassides olid laste tulemused klassi lõpus oluliselt paremad kui õpetajakeskse ja laps-domineeriva stiiliga õpetajate klassides. CFA näitas lisaks, et kui lapsekeskse kasvatusstiiliga õpetajate klassides oli häid tekstimõistjaid suhteliselt palju ja kehvade mõistmisoskustega õpilasi vähe, siis õpetajakeskse ja laps-domineeriva kasvatusstiiliga õpetajate klassides ilmnes vastupidine tendents: häid 
tekstimõistjaid oli suhteliselt vähe ja madala tekstimõistmisoskuse tasemega lapsi suhteliselt palju. Võib arvata, et positiivsed seosed õpetaja lapsekeskse kasvatusstiili ja laste loetu mõistmise vahel on seotud sellega, et õpetaja rõhuasetused õppimisel (sh lugemises) on suunatud mõistmisele, ta kasutab laste oskuste toetamisel mitmekesiseid õpetamisvõtteid ning rõhutab ja jälgib õppimisel arusaamist (McCombs, 2010; Stipek \& Byler, 2004). Meie tulemused lubavad järeldada, et õpetajakeskse stiili domineerimine õpetaja tegevustes, mis on suunatud pigem põhioskuste treenimisele ning vähem õpitava mõtestamisele, ei mõju laste loetu mõistmise arengule soodsalt. Laps-domineeriva kasvatusstiiliga klasside õpilaste halvad tulemused kinnitavad omakorda, et õpikeskkond, millele on iseloomulik vähene õpetajapoolne suunamine ja toetus, ei soodusta laste loetu mõistmise arengut algklassides (Stipek \& Byler, 2004; Walker, 2008). Loetu mõistmine on keerukas kognitiivne protsess, mis hõlmab peale sõnade kokkulugemise ja teksti otsesest tähendusest arusaamise ka varasemate taustteadmiste aktualiseerimist ning järelduste ja üldistuste tegemist (Kintsch, 1998, 2013). Teksti täielik mõistmine eeldab seega mitmeid teadmisi ja oskusi, aga ka pingutamist ja püsivust. Siinse uurimuse tulemused näitavad selgelt, kui vajalik on laste tekstimõistmisoskuse arengus õpetaja suunav ja toetav roll.

Kolmanda hüpoteesina oletasime, et laste motivatsiooniga, st lugemishuvi ja tajutud võimekusega, seostub positiivselt vaid lapsekeskne kasvatusstiil, mille korral õpetaja väärtustab laste huvisid, rakendab huvi tekitavaid tegevusi ja toetab lapsi õppimisel emotsionaalselt (McCombs, 2010; Stipek \& Byler, 2004). Püstitatud hüpotees leidis kinnitust lugemishuvi osas, mis oli lapsekeskse kasvatusstiiliga õpetajate klasside lastel klassi lõpus keskmiselt suurem kui õpetajakeskse ja laps-domineeriva stiiliga klasside lastel. CFA näitas lisaks, et lapsekeskse stiiliga õpetajate klassides oli suhteliselt vähe väikese lugemishuviga õpilasi, seevastu lapsdomineeriva stiiliga klassides oli väikese lugemishuviga laste sagedus suur ning lugemisest huvitatud lapsi vähe. Seega erinevalt õpetajakesksest stiilist avaldavad lapsekesksed kasvatustegevused laste lugemishuvile positiivset mõju, mida on leitud ka varem (Lerkkanen et al., 2012b). Siinsed tulemused täiendavad olemasolevaid teadmisi sellest, kuidas seostub laps-domineeriva stiili puhul õpetajate kasvatustegevus ja laste motivatsioon, näidates, et algklassides ei toeta lastele liigne vabaduse andmine - st vähene suunamine ja tugi õppimisel - nende lugemishuvi säilimist. Huvi on aga lugemisoskuse arengu üks põhieeldusi, mistõttu on selle tähtsust raske ülehinnata. Kui lugemine on rahulolu pakkuv tegevus, loeb laps 
ka vabal ajal rohkem, mis omakorda aitab kaasa tema edasisele lugemisoskuse arengule (Becker et al., 2010).

Tajutud lugemisvõimekuses hüpotees kinnitust ei leidnud: erinevate kasvatusstiilidega õpetajate klasside õpilaste tajutud võimekuses erinevusi ei ilmnenud. Klassi alguses hindas enamik lapsi enda toimetulekut lugemises väga heaks ning ka klassi lõpus olid vastavad hinnangud kõrged, olenemata õpetaja kasvatusstiilist. Võib oletada, et tajutud võimekuses leitud erinevused, mis põhinevad õpetaja tagasisidel lapse tulemuste kohta ning sotsiaalse võrdluse teel saadud teabel (Schunk, 1999; Zimmerman, 2000), hakkavad ilmnema mõnevõrra hiljem.

\section{Uurimuse piirangud}

Siinsel uurimusel on mitu piirangut, mida tuleks tulemuste tõlgendamisel arvesse võtta. Esiteks, saadud tulemustele võis avaldada mõju uuringus osalenud õpetajate väike arv. Teiseks, töös uurisime õpetajate kasvatusstiilide seoseid laste oskuste ja motivatsiooniga üldiselt, kuigi on teada, et õpetaja tegevuse efektiivsus on seotud ka laste olemasolevate oskuste tasemega (nt Connor et al., 2004, 2009a). Kolmandaks, uurimuses võtsime aluseks õpetajate kasvatusstiilid, mis kajastavad mingit tüüpi tegevuste domineerimist, mitte ainukasutamist. Reaalselt kasutavad õpetajad kõiki kolme tüüpi tegevusi, mida siinses uurimuses ei ole arvestatud. Neljandaks, kasutatud vaatlusmõõdik ECCOM (Stipek \& Byler, 2005) ei anna teavet õpetaja lugemaõpetamise meetodite kohta, millel samuti on suur mõju laste lugemisoskuse arengule (Connor et al., 2004, 2009a, 2009b; Wigfield et al., 2004). Edaspidi on plaanis uurida ka seoseid õpetajate ainespetsiifiliste õpetamistegevuste ja laste lugemisoskuse arengu vahel.

\section{Kokkuvõte}

On teada, et algklassides omandatud lugemisoskusel ja motivatsioonil on tähtis koht laste edasises kooliedukuses. Õpetaja tegevuste ja õpilaste arengu seoste kohta on teada vähem. Siinne töö keskendus õpetaja kasvatusstiilide ning laste lugemisoskuse ja -motivatsiooni seostele esimeses klassis. Tulemused näitasid, et õpetaja kasvatusstiilid on laste oskuste ja ópimotivatsiooniga oluliselt seotud. Laste lugemisoskuse ja -motivatsiooni arengut toetab lapsekeskne kasvatusstiil, mis lähtub õpilase individuaalsetest vajadustest ning millega püütakse kujundada õpitava mõistmisele, huvi äratamisele ja meisterlikkusele suunatud õpikäitumist. Seevastu õpetajakesksete ja laps-domineerivate tegevuste ülekaal õpetaja käitumises pigem pärsib algklassiõpilaste lugemisoskuse arengut ega toeta 
lugemishuvi püsimist. Uuringu tulemusi saab kasutada õpetajate tasemeja täienduskoolituses.

\section{Tänusõnad}

Artikkel on valminud Euroopa Sotsiaalfondi programmi Eduko (grant 30.2-4/549) ja Eesti Teadusagentuuri (grant IUT03-03) toel. Täname uuringus osalenud lapsi ja õpetajaid ning Marge Kimmelit, Marie Maarendit, Katrin Mäge ja Airi Niilot tunnivaatluste eest.

\section{Kasutatud kirjandus}

Aunola, K., Nurmi, J.-E., Niemi, P., Lerkkanen, M.-K., \& Rasku-Puttonen, H. (2002). Developmental dynamics of achievement strategies, reading performance and parental beliefs. Reading Research Quarterly, 37(3), 310-327. http://dx.doi.org/10.1598/RRQ.37.3.3

Bandura, A. (1986). Social foundations of thought and action: A social cognitive theory. Englewood Cliffs, New Jersey: Prentice-Hall.

Becker, M., McElvany, N., \& Kortenbruck, M. (2010). Intrinsic and extrinsic reading motivation as predictors of reading literacy: A longitudinal study. Journal of Educational Psychology, 102(4), 773-785. http://dx.doi.org/10.1037/a0020084

Bergman, L. R., \& El-Khouri, B. M. (2002). Sleipner 2.1. Retrieved from http://www2. psychology.su.se/sleipner/.

Cain, K. (2009). Children's reading comprehension difficulties: A consideration of the precursors and consequences. In C. Wood \& V. Connelly (Eds.), Contemporary Perspectives on Reading and Spelling (pp. 59-75). London: Routledge.

Connor, C. M., Morrison, F. J., Fishman, B. J., Ponitz, C. C., Glasney, S., Underwood, P. S., ... Schatschneider, C. (2009a). The ISI classroom observation system: Examining the literacy instruction provided to individual students. Educational Researcher, 38(2), 85-99. http://dx.doi.org/10.3102/0013189X09332373

Connor, C. M., Morrison, F. J., \& Katch, L. E. (2004). Beyond the reading wars: Exploring the effects of child-instruction interactions on growth in early reading. Scientific Studies of Reading, 8(4), 305-336. http://dx.doi.org/10.1207/s1532799xssr0804_1

Connor, C. M., Piasta, S. B., Fishman, B., Glasney, S., Schatschneider, C., Crowe, E., ... Morrison, F. J. (2009b). Individualizing student instruction precisely: Effects of child $\times$ instruction interactions on first graders' literacy development. Child Development, 80(1), 77-100. http://dx.doi.org/10.1111/j.1467-8624.2008.01247.x

Daniels, D. H., \& Shumow, L. (2003). Child development and classroom teaching: A review of the literature and implications for educating teachers. Applied Developmental Psychology, 23(5), 495-526.

http://dx.doi.org/10.1016/S0193-3973(02)00139-9 
Deci, E., \& Ryan, R. (2000). The „what” and „why” of goal pursuits: Human needs and the self-determination of behavior. Psychological Inquiry, 11(4), 227-268. http://dx.doi.org/10.1207/S15327965PLI1104_01

Eccles, J. S., \& Wigfield, A. (2002). Motivational beliefes, values, and goals. Annual Review of Psychology, 53, 109-132. http://dx.doi.org/10.1146/annurev.psych.53.100901.135153

Eccles, J., Wigfield, A., Harold, R. D., \& Blumenfeld, P. (1993). Age and gender differences in children's self and task perceptions during elementary school. Child Development, 64(3), 830-847. http://dx.doi.org/10.2307/1131221

Georgiou, G. K., Parrila, R., \& Papadopoulos, T. C. (2008). Predictors of word decoding and reading fluency across languages varying in orthographic consistency. Journal of Educational Psychology, 100(3), 566-580. http://dx.doi.org/10.1037/0022-0663.100.3.566

Gettinger, M., \& Kohler, K. M. (2011). Process-outcome approaches to classroom management and effective teaching. In C. M. Evertson \& C. S. Weinstein (Eds.), Handbook of classroom management: Research, practice, and contemporary issues (pp. 73-95). New York, London: Routledge.

Gottfried, A. E. (1990). Academic intrinsic motivation in young elementary school children. Journal of Educational Psychology, 82(3), 525-538. http://dx.doi.org/10.1037/0022-0663.82.3.525

Guthrie, J. T., Hoa, A. L. W., Wigfield, A., Tonks, S. M., Humenick, N. M., \& Littles, E. (2007). Reading motivation and reading comprehension growth in the later elementary years. Contemporary Educational Psychology, 32(3), 282-313. http://dx.doi.org/10.1016/j.cedpsych.2006.05.004

Guthrie, J., Wigfield, A., \& Von Secker, C. (2000). Effects of integrated instruction on motivation and strategy use in reading. Journal of Educational Psychology, 92(2), 331-341. http://dx.doi.org/10.1037/0022-0663.92.2.331

Hamre, B., \& Pianta, R. (2010). Classroom environments and developmental processes: Conceptualization and measurement. In J. L. Meece \& J. S. Eccles (Eds.), Handbook of research on schools, schooling, and human development (pp. 25-41). New York, London: Routledge.

Hoover, W. A., \& Gough, P. B. (1990). The simple view of reading. Reading and Writing, 2(2), 127-160. http://dx.doi.org/10.1007/BF00401799

Häyrinen, T., Serenius-Sirve, S., \& Korkman, M. (1999). Lukilasse. Helsinki: Psykologien kustannus.

Kalev, L. (2008). Lugemisoskuse tase esimeses klassis (Magistritöö). Tartu Ülikool, Tartu.

Kintsch, W. (1998). Comprehension: A paradigm for cognition. New York: Cambridge University Press.

Kintsch, W. (2013). Revisiting the construction-integration model of text comprehension and its implications for instruction. In D. E. Alvermann, N. J. Unrau, \& R. B. Ruddell (Eds.), Theoretical models and processes of reading (pp. 807-839). Newark, Delaware: International Reading Association. http://dx.doi.org/10.1598/0710.32 
Landerl, K., \& Wimmer, H. (2008). Development of word reading fluency and spelling in a consistent orthography: An 8-year follow-up. Journal of Educational Psychology, 100(1), 150-161. http://dx.doi.org/10.1037/0022-0663.100.1.150

Lepola, J., Niemi, P., Kuikka, M., \& Hannula, M. M. (2005). Cognitive-linguistic skills and motivation as longitudinal predictors of reading and arithmetic achievement: A follow-up study from kindergarten to grade 2. International Journal of Educational Research, 43(4-5), 250-271. http://dx.doi.org/10.1016/j.ijer.2006.06.005

Lerkkanen, M.-K., Kikas, E., Pakarinen, E., Trossmann, K., Poikkeus, A.-M., RaskuPuttonen, H., ... Nurmi, J.-E. (2012a). A validation of the Early Childhood Classroom Observation Measure in Finnish and Estonian kindergartens. Early Education and Development, 23(3), 323-350.

http://dx.doi.org/10.1080/10409289.2010.527222

Lerkkanen, M.-K., Kiuru, N., Pakarinen, E., Viljaranta, J., Poikkeus, A.-M., RaskuPuttonen, H., ... Nurmi, J.-E. (2012b). The role of teaching practices in the development of children's interest in reading and mathematics in kindergarten. Contemporary Educational Psychology, 37(4), 266-279.

http://dx.doi.org/10.1016/j.cedpsych.2011.03.004

Lindeman, J. (1998). ALLU - Ala-asteen lukutesti. Åbo: Åbo Akademis förlag.

McCombs, B. (2010). Learner-centered practices: Providing the context for positive learner development, motivation, and achievement. In J. L. Meece \& J. S. Eccles (Eds.), Handbook of research on schools, schooling, and human development (pp. 60-74). New York, London: Routledge.

McGraw, K. O., \& Wong, S. P. (1996). Forming inferences about some intraclass correlation coefficients. Psychological Methods, 1(1), 30-46. http://dx.doi.org/10.1037/1082-989X.1.1.30

Mõttus, M. (2013). Sõnade äratundmise testi katsetamine 1.-3. klassi õpilaste lugemisoskuse hindamisel (Seminaritöö). Tallinna Ülikooli psühholoogia instituut.

Oakhill, J., \& Cain, K. (2007). Introduction to comprehension development. In K. Cain \& J. Oakhill (Eds.), Children's comprehension problems in oral and written language: A cognitive perspective (pp. 3-40). New York: The Guilford Press.

Perfetti, C. A. (1994). Psycholinguistics and reading ability. In M. A. Gernsbacher (Ed.), Handbook of psycholinguistics (pp. 849-894). San Diego: Academic Press.

Perry, K. E., Donohue, K. M., \& Weinstein, R. S. (2007). Teaching practices and the promotion of achievement and adjustment in first grade. Journal of School Psychology, 45(3), 269-292. http://dx.doi.org/10.1016/j.jsp.2007.02.005

Ryan, R. M., \& Deci, E. L. (2000). Intrinsic and extrinsic motivations: Classic definitions and new directions. Contemporary Educational Psychology, 25(1), 54-67. http://dx.doi.org/10.1006/ceps.1999.1020

Schunk, D. H. (1999). Social-self interaction and achievement behavior. Educational Psychologist, 34(4), 219-227. http://dx.doi.org/10.1207/s15326985ep3404_3

Soodla, P., Vija, M., \& Pajusalu, R. (2013). Eesti ja soome sõnalugemistestide võrdlus. Eesti Rakenduslingvistika Ühingu aastaraamat, 9, 279-296.

http://dx.doi.org/10.5128/ERYa9.18

Stipek, D., \& Byler, P. (2004). The early childhood classroom observation measure. Early Childhood Research Quarterly, 19(3), 375-397.

http://dx.doi.org/10.1016/j.ecresq.2004.07.007 
Stipek, D., \& Byler, P. (2005). Early childhood classroom observation measure: Coding manual. Retrieved from authors electronically.

Stipek, D. J., Feiler, R., Byler, P., Ryan, R., Milburn, S., \& Miller Salmon, J. (1998). Good beginnings: What difference does the program make in preparing young children for school? Journal of Applied Developmental Psychology, 19(1), 41-66. http://dx.doi.org/10.1016/S0193-3973(99)80027-6

Stipek, D., \& MacIver, D. (1989). Developmental change in children's assessment of intellectual competence. Child Development, 60(3), 521-538. http://dx.doi.org/10.2307/1130719

Zimmerman, B. J. (2000). Self-efficacy: An essential motive to learn. Contemporary Educational Psychology, 25(1), 82-91. http://dx.doi.org/10.1006/ceps.1999.1016

Torppa, M., Eklund, K., van Bergen, E., \& Lyytinen, H. (2011). Parental literacy predicts children's literacy: A longitudinal family-risk study. Dyslexia, 17(4), 339355. http://dx.doi.org/10.1002/dys.437

Vabariigi Valitsus (2010). Põhikooli riiklik õppekava. Riigi Teataja I 2010, 6, 22. Külastatud aadressil https://www.riigiteataja.ee/akt/13273133.

Walker, J. M. T. (2008). Looking at teacher practices through the lens of parenting style. The Journal of Experimental Education, 76(2), 218-240. http://dx.doi.org/10.3200/JEXE.76.2.218-240

Wentzel, K. (2010). Students' relationships with teachers. In J. L. Meece \& J. S. Eccles (Eds.), Handbook of research on schools, schooling, and human development (pp. 75-91). New York, London: Routledge.

Wigfield, A., \& Eccles, J. S. (2000). Expectancy-value theory of achievement motivation. Contemporary Educational Psychology, 25(1), 68-81. http://dx.doi.org/10.1006/ceps.1999.1015

Wigfield, A., \& Guthrie, J. T. (1997). Relations of children's motivation for reading to the amount and breath of their reading. Journal of Educational Psychology, 89(3), 420-432. http://dx.doi.org/10.1037/0022-0663.89.3.420

Wigfield, A., Guthrie, J. T., Tonks, S., \& Perencevich, K. C. (2004). Children's motivation for reading: Domain specificity and instructional influences. The Journal of Educational Research, 97(6), 299-309. http://dx.doi.org/10.3200/JOER.97.6.299-310

Wilson, K. M., \& Trainin, G. (2007). First-grade students' motivation and achievement for reading, writing, and spelling. Reading Psychology, 28(3), 257-282. http://dx.doi.org/10.1080/02702710601186464 


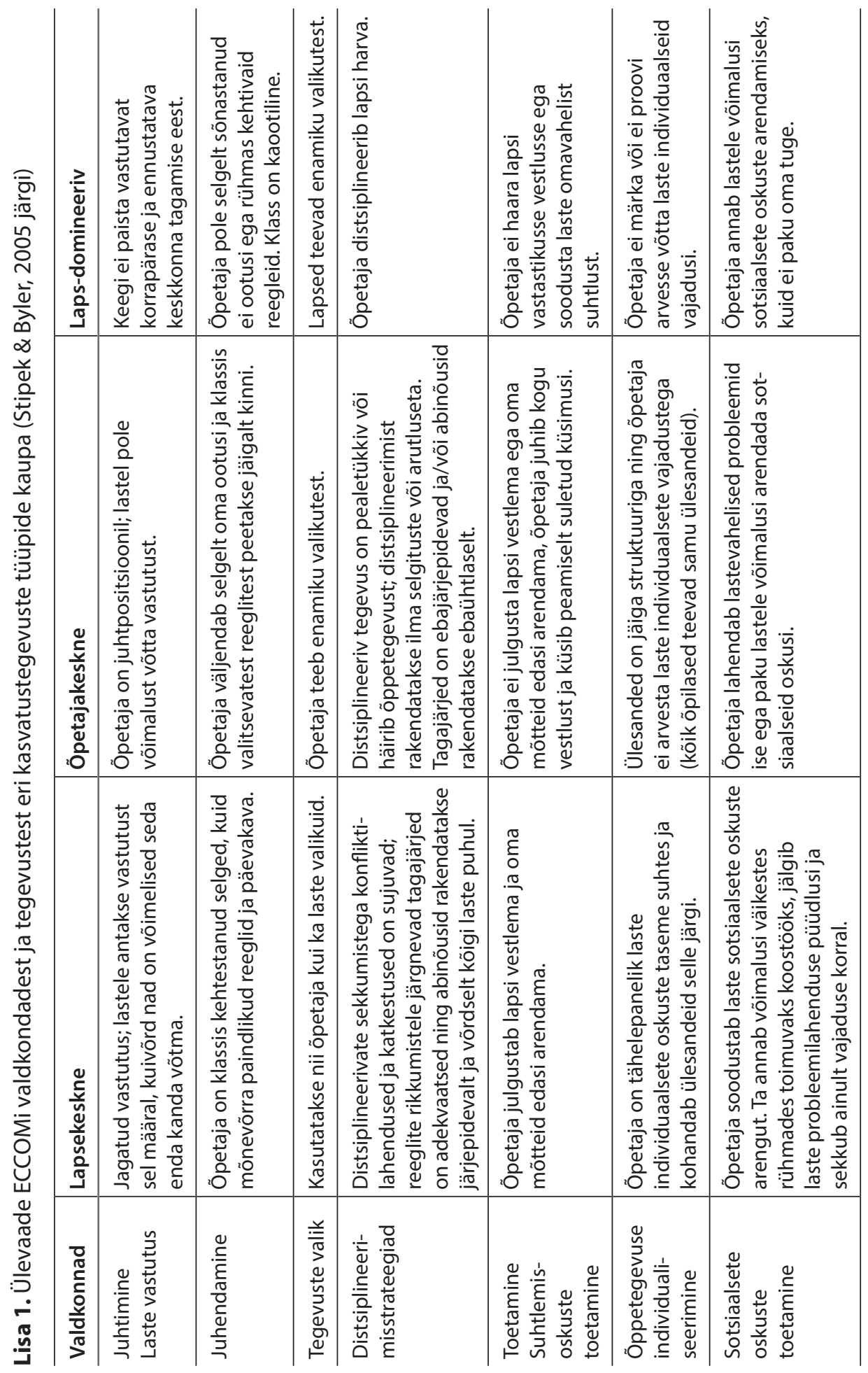




\begin{tabular}{|c|c|c|c|c|c|c|c|}
\hline 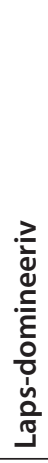 & 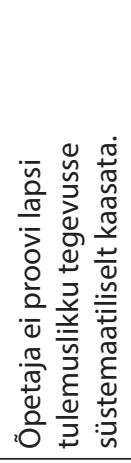 & 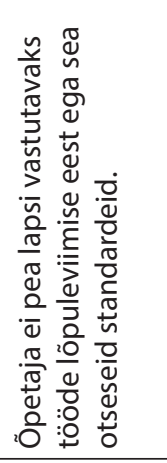 & 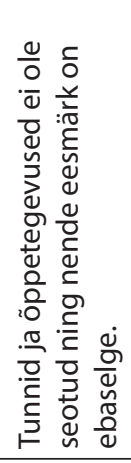 & 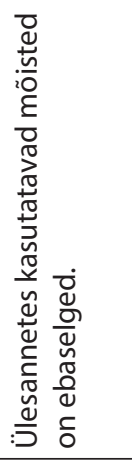 & 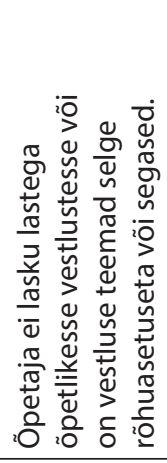 & 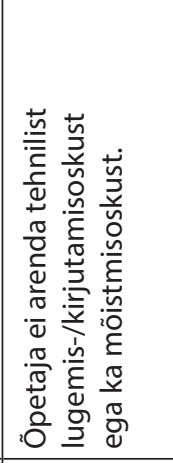 & 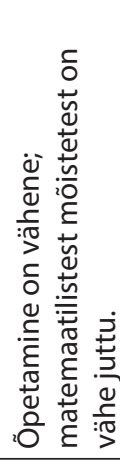 \\
\hline 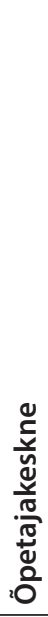 & 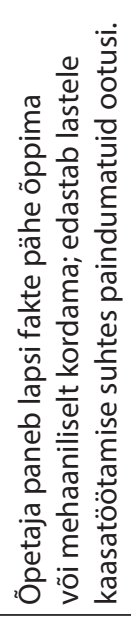 & 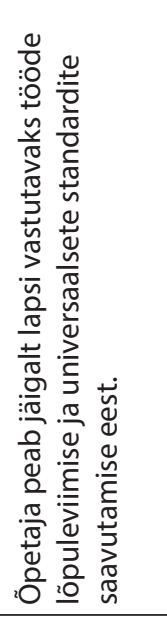 & 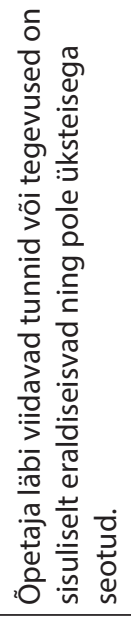 & 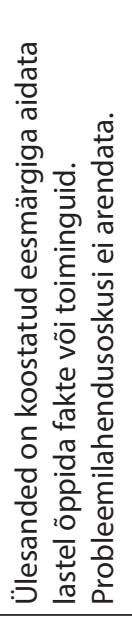 & 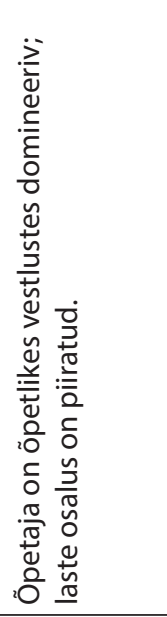 & 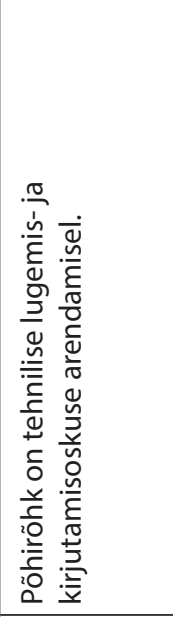 & 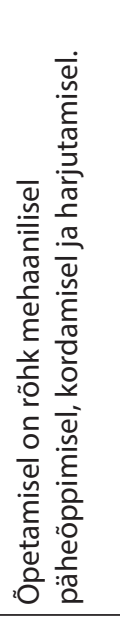 \\
\hline 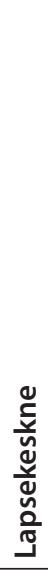 & 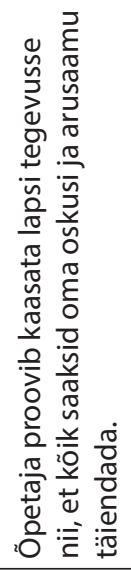 & 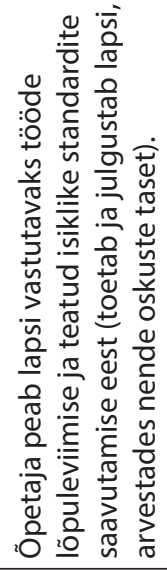 & 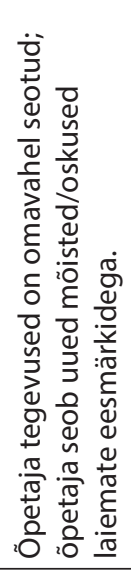 & 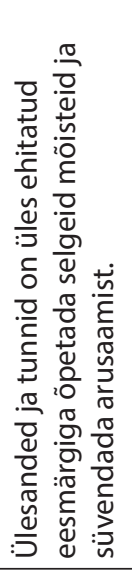 & 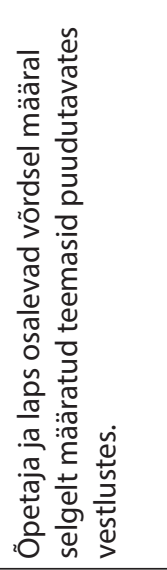 & 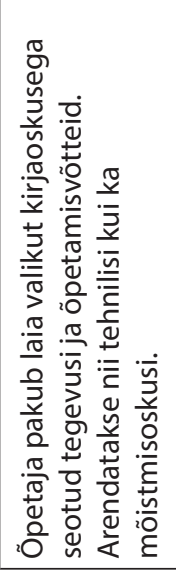 & 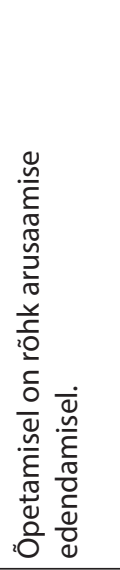 \\
\hline 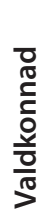 & 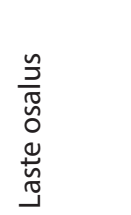 & 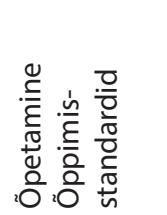 & 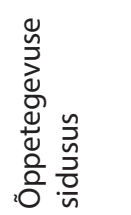 & 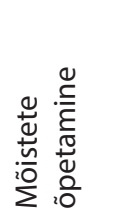 & 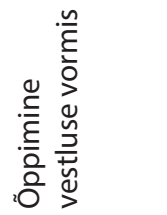 & 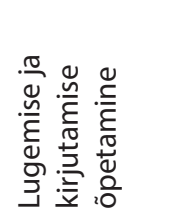 & 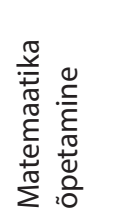 \\
\hline
\end{tabular}




\title{
Relations of reading skills and motivation with teaching styles in first grade
}

\author{
Piret Soodla $^{\text {al }}$, Eve Kikas ${ }^{\mathrm{a}}$ \\ a Tallinn University, Institute of Psychology
}

\begin{abstract}
Summary
Learning to read is one of the most important objectives during the first school years. Various cognitive and linguistic skills (see Cain, 2009; Oakhill \& Cain, 2007) and motivational factors (see Aunola et al., 2002; Guthrie et al., 2000; Wigfield \& Guthrie, 1997; Wilson \& Trainin, 2007) are prerequisite to reading comprehension. During the past few decades, studies on reading have focused attention on teacher's activities in class which also has a significant effect on children's development (e.g. Connor et al., 2009a, 2009b; Lerkkanen et al., 2012b; Wigfield et al., 2004). However, few observation-based longitudinal studies have been conducted.
\end{abstract}

\section{The objectives and hypotheses of the study}

The aim of the study was to analyse whether first grade students' reading skills and motivation differed in the classes where teachers used childcentred, teacher-centred and child-dominant teaching styles and how. The following hypotheses were posed:

1. Regarding connections between the teachers' teaching styles and students' word reading skills, we posed two alternative hypotheses. First, we expected (Hypothesis 1a) that the teacher-centred teaching style is positively related to children's word reading skills, as the teacher focuses on practicing the students' technical skills, i.e. fluency and accuracy of reading (Gettinger \& Kohler, 2011); the relations between child-centred style and children's skills are weaker because the teacher does not pay as much attention to practicing word reading skills as to comprehension (Stipek \& Byler, 2004), and the child-dominant style relates negatively to the child's skills (Walker, 2008). Alternatively, we expected (Hypothesis 1b) that both child-centred and teacher-centred teaching styles are positively associated with children's word reading

1 Institute of Psychology, Tallinn University, Narva Road 29, 10120 Tallinn, Estonia; piret.soodla@tlu.ee 
skills - as the teacher-centred activities direct the child to practicing, children's motivation is enhanced by child-centred activities, which in turn may make children work harder (Connor et al., 2004, 2009b; Gettinger \& Kohler, 2011; Perry et al., 2007); child-dominant teaching style is negatively connected to children's development (Walker, 2008).

2. We expected (Hypothesis 2) that the child-centred teaching style is positively related to reading comprehension as the teacher emphasises developing children's comprehension skills in general and encourages them to make an effort (McCombs, 2010; Stipek \& Byler, 2004; Wentzel, 2010); reading comprehension is less supported by the teacher-centred style which gives the priority to mechanical training of basic skills (Stipek \& Byler, 2004), while the child-dominant teaching style relates negatively to the development of children's comprehension skills (Walker, 2008).

3. We expected (Hypothesis 3) that only the child-centred teaching style is positively associated with children's motivation, as the teacher values the children's interests, and encourages and supports them in studies emotionally; the teacher-centred and child-dominant styles relate negatively to children's motivation, because emotional support and the consideration of the children's interests is scarce from the teacher's part (McCombs, 2010; Stipek \& Byler, 2004; Wentzel, 2010).

\section{Method}

First grade students $(N=440)$ and their teachers $(N=21)$ participated in the study. Children's word reading skills and motivation were assessed at the beginning and the end of first grade; reading comprehension was assessed at the end of first grade. In each class, three lessons were observed and class activities were coded by means of the ECCOM coding measure (Stipek \& Byler, 2005). The teachers were divided according to their approach as practising child-centred $(n=8)$, teacher-centred $(n=7)$ and child-dominant $(n=6)$ styles based on the observation.

In the data analyses, variable-oriented methods (one-way ANOVA) were combined with person-oriented methods (Configural Frequency Analysis, CFA, see Bergman \& El-Khouri, 2002).

\section{Results and conclusions}

Teaching styles and students' word reading skills. While there were no differences in word reading skills in classes of teachers with different styles at the beginning of the first grade, at the end of the year these skills 
were better in the classes of teachers with a child-centred style compared to teachers practicing the other styles. CFA revealed differences in the relative incidence of poor readers between the groups of teachers: in child-centred classes, there were relatively few poor readers, but relatively many in teacher-centred classes. Although previous research has pointed out that it is the weak students that need to be taught specific elementary skills and practice them, and this is offered by teacher-centred methods (see Connor et al., 2004, 2009b; Stipek \& Byler, 2004), our results rather show that it the child-centred style that has a favourable influence on children's word reading skills. The child-dominant style linked negatively to students' word reading skills, which confirms previous results (Walker, 2008).

Teaching styles and students' reading comprehension. The child-centred teaching style associated positively with students' reading comprehension. The children's results were significantly better at the end of the school year in the classes of teachers practising predominantly child-centred teaching activities compared to the classes of teachers with teachercentred and child-dominant styles. CFA also revealed a relatively large number of students with good reading comprehension skills and less with poor comprehension skills in the student-centred classes, but the tendency was the contrary in the classes of teachers with teachercentred and child-dominant styles. It may be assumed that the positive relationship between the teacher's child-centred teaching style and children's reading comprehension derive from the teacher's concentration on comprehension skills (McCombs, 2010; Stipek \& Byler, 2004). Our study showed that the dominance of the teacher-centred style in teacher's activities does not favour the children's development. Low results in children in child-dominant classes confirm the understanding that such a learning environment does not contribute to the development of children's skills (Stipek \& Byler, 2004; Walker, 2008).

Teaching styles and students' reading motivation. As expected, only the child-centred teaching style related positively to children's interest in reading. While there were no differences in the level of reading interest in the classes of teachers with different teaching styles at the beginning of the first grade, the level was the highest in the classes of child-centred teachers by the end of the grade. CFA also revealed that there were relatively few students with a low level of reading interest in the classes of child-centred teachers, in contrast to the child-dominant classes, 
where the frequency of children with low reading interest was high and few children were interested in reading. Continuously high interest in reading can be explained by the activities of a child-centred teacher which are characterised by valuing the children's interests, applying interestprovoking educational activities and supporting children emotionally in learning (McCombs, 2010; Stipek \& Byler, 2004). The results are consistent with the findings of Lerkkanen et al. (2012b) - compared to the teacher-centred style, a dominance of child-centred activities in the teacher's behaviour positively influences children's reading interest. Results show that in primary school, the child-dominant style does not support children's internal motivation. Results of the study did not show associations between teaching styles and children's self-efficacy. It appeared that at the end of first grade self-efficacy was homogeneously high in the classes of teachers with all teaching styles. It may be presumed that differences in students' self-efficacy will become apparent during a longer period of time.

Conclusion. The study concentrated on the relationships of teaching styles with children's reading skills and motivation in the first grade. The results revealed that teaching styles are significantly related to children's skills and motivation. The development of children's reading skills and motivation is supported by the child-centred teaching style that is inspired by the child's individual needs and is oriented to comprehension and shaping the learning behaviour that is directed towards attracting interest and masterfulness. The dominance of teacher-centred and child-dominant activities in the teacher's behaviour, on the contrary, tend to hinder the development of primary school students' reading skills and fail to support interest in reading. The results of the study are also applicable in teacher education programmes.

Keywords: teaching practices, teaching styles, reading, motivation, interest, self-efficacy 